\title{
Floriculture and Covid-19
}

\author{
Márkilla Zunete Beckmann-Cavalcante* (1) \\ Editor-in-chief Ornamental Horticulture; Universidade Federal do Vale do São Francisco, \\ Colegiado de Engenharia Agronômica, Petrolina-PE, Brazil.
}

Floriculture, especially in Brazil, is an activity in expressive grown. Since 2006, the Flower production segment has registered increases of $5 \%$ to $8 \%$, and until the end of 2019 , there was an expectation of growth of $8 \%$ to $10 \%$ (Ibraflor, 2019). However, it was not imagined that a global health problem could cause a worldwide crisis in several sectors, as well as in Floriculture. On January 30, 2020, the World Health Organization (WHO) declared that the outbreak of the new Coronavirus (2019-nCoV) constituted a Public Health Emergency of International Importance (ESPII). This was how Covid-19 emerged, a disease caused by Sars-Cov-2 (PAHO, 2020) and, on March 11 of the same year, WHO declared the Covid-19 pandemic.

The whole world took action to prevent the spread of the new Coronavirus. In Brazil, a period of sanitary emergency was entered on February 4 (BRASIL, 2020), even before the confirmation of the first case in the country, which was February 26, 2020. In view of the situation, several restrictive and social isolation measures were taken. And once again, in the midst of chaos, it was realized that agriculture has been the motor of the Brazilian economy. However, not all agricultural crops and operations have emerged unscathed from the economic impact caused by the pandemic. Many producers, especially small ones, had problems in commercialization of their products. Sectors such as Floriculture felt the impact of falling sales (Okumura, 2020).

In a brief report, still on March 28, 2020, the Brazilian Institute of Floriculture (Ibraflor, 2020a), released a warning for a devastating scenario for national Floriculture if the rules were not relaxed to allow to reactivate the economy and the commercialization of flowers and plants. Unemployment was estimated at 120,000 people in the productive areas. In just two weeks after the beginning of Covid-19 in Brazil, in the entire chain, the calculated amount that was no billed totalled R\$ 297.7 million. Consequence of the halt in the sale of flower and ornamental plant due to the cancellation of events and closing of points of sale.

Therefore, a Crisis Committee was created, formed by the main leaders of the sector installed in Holambra, in the State of São Paulo, such as Ibraflor, Veiling Holambra and Cooperflora. Among the first actions, an appeal was made to the Federal Government, through the Ministry of Agriculture and Supply (MAPA) and the State governments to relax the rules for Floriculture, as it is an essential service and part of agribusiness, because it moves around $\mathrm{R} \$ 8.7$ billion in the entire chain, generating thousands of jobs across the country (Ibraflor, 2020a).

After a chaotic scenario, the floriculture sector, which suffered at the beginning of the crisis, is already showing signs of recovery, with adaptations for the use of technology and e-commerce of flowers, connecting directly to its final consumers (Okumura, 2020). However more than that, several other strategies were taken to avoid more drastic falls in the sector, such as campaigns, disclosures and movements through social networks, using phrases: "Flowers and Plants, Food for the Soul"; "Flowers for well-being"; "Rebook, don't cancel your event"; "Having plants at home is having peace and joy every day"; "Nature doesn't stop. We neither"; "Flowers relieve stress, fear and anxiety"; "Make meals even more colorful with flowers"; "Hug with flowers", among others (Ibraflor, 2020c; Cooperflora, 2020, Veiling Holambra, 2020)

Allied to the campaigns, notably several other virtual movements were emerging emphasizing the benefits of flowers and ornamental plants during the Covid-19 pandemic, such as channels on YouTube, Instagram and Facebook. As reported by Reis et al., (2020), with the crisis faced by the sector, organizations from different areas, both public and / or private, aimed at informing the public, producers and technicians about the situation of floriculture. Several lives - live streams - were organized, providing interviews about floriculture, from production to commercialization. These movements were important to emphasize resilience, that is, adapting to changes and making the wheel spin again.

If on the one hand there were losses in business, or even opportunism due to the chaotic situation, on the other hand, opportunities may be seen. There was a need to plan actions collectively or individually to minimize losses. There was a need to start working to reverse the situation. There was a need to develop entrepreneurship. And with all these changes brought about by the pandemic, it was observed that forgotten habits or little or nothing practiced started to be part of the routine in times of social isolation, promoting reconnection with nature, rediscovering the purposes of life and taking care of more health.

The practice of activities such as gardening and horticulture, composition of floral arrangements, are part of the routine of human beings as strong allies for health

*Corresponding author: markilla.beckmann@univasf.edu.br 
and well-being in times of pandemic. In this context, there are several business possibilities when using flowers and ornamental plants. According to Aki (2020), garden centers for example, will be a new hobby option for people, who will act as decompression centers, helping people to find their new purpose in life, such as: living spaces, ambient sound, easy navigation, motivator and handmade hobbyist (home gardening, urban jungle, horticulture), among others. Thinking about the producers, the same author refers to the emergence of new opportunities such as joint promotional actions with retailers, retail events, rural tourism, space rental of the farm for weddings and events, and support for social campaigns. That is, offering better experiences and with the strengthening of the flower chain, also favouring regional development.

Considering that the pandemic has changed the social scenario in recent times and has brought impacts of different orders to people's lives, it is noted that plants have been a refuge to maintain mental health and emotional balance, and it has also promoted new opportunities for Business. Among the plants, the category of flower and ornamental plants has helped in this journey.

\section{References}

AKI, A. Uma visão sobre o ecossistema de flores na região de Maringá e seus potenciais encaminhamentos. 2020. Available at: https://www.negocioscomflores.com.br/noticias/uma-visao-sobre-o-ecossistema-de-flores-na-regiao-demaringa-e-seus-potenciais-encaminhamentos/ Accessed on: Oct 26, 2020.

BRASIL, 2020. Diário Oficial da União. Ministério da Saúde. Gabinete do Ministro. Portaria No 188 , de 3 de fevereiro de 2020. Available at: https://www.in.gov.br/en/web/dou/-/portaria-n-188-de-3-de-fevereiro-de-2020-241408388 Accessed on: Oct 26, 2020.

IBRAFLOR. Instituto Brasileiro de Floricultura. 2019. O mercado de flores no Brasil. Available at: https://www.ibraflor. com.br/numeros-setor Accessed on: Oct 20, 2020.

IBRAFLOR. Instituto Brasileiro de Floricultura. 2020a. Ibraflor prevê falência de $66 \%$ dos produtores de flores e de plantas ornamentais. Available at: https:/www.ibraflor.com.br/post/ibraflor-prev\%C3\%AA-fal\%C3\%AAncia-de-66dos-produtores-de-flores-e-de-plantas-ornamentais Accessed on: Oct 20, 2020.

IBRAFLOR. Instituto Brasileiro de Floricultura. 2020b. Instagram: @ibraflor. Available at: https://www.instagram.com/ ibraflor/ Accessed on: Oct 26, 2020

COOPERFLORA. 2020. Instagram: @ cooperflora. Available at: https://www.instagram.com/cooperflora/ Accessed on: Oct 26, 2020.

OKUMURA, R. The technological impacts of the pandemic on agribusiness. 2020. Available at: https://www.venturus. org.br/en/the-technological-impacts-of-the-pandemic-on-agribusiness/ Accessed on: Oct 26, 2020.

PAHO. Pan American Health Organization. 2020. OMS declara emergência de saúde pública de importância internacional por surto de novo Coronavírus. Available at: https:/www.paho.org/bra/index.php?option=com content\&view=article \&id=6100:oms-declara-emergencia-de-saude-publica-de-importancia-internacional-em-relacao-anovo-coronavirus\&Itemid=812 Accessed on: Oct 20, 2020.

REIS, S.N.; REIS, M.V.; NASCIMENTO, Â.M.P. Pandemic, social isolation and the importance of people-plant interaction. Ornamental Horticulture, v.26, n.3, 399-412, 2020. DOI: https://doi.org/10.1590/2447-536X.v26i3.2185

VEILING HOLAMBRA. Instagram: @veilingholambra. Available at: https://www.instagram.com/veilingholambra/ Accessed on: Oct 26, 2020. 